\title{
Present status and upcoming prospects of hedgehog pathway inhibitors in small cell lung cancer therapy
}

\author{
Syed Hassan Abbas Naqvi", Syed Hassan Shiraz Naqvi, Muhammad Yasin Bandukda and Syed Mumtaz Ali Naqvi
}

\begin{abstract}
Lung cancer is an important etiology of malignant mortality worldwide with global statistics indicating over 1 million deaths annually. Although there have been advances in cytotoxic chemotherapy, the prognosis after treatment still remains poor. Remarkably, recent studies on the molecular level are creating the possibility to hamper lung cancer by inhibiting the hedgehog pathway. Currently, hedgehog pathway inhibitors include IWP-2, cyclopamine and aprotinin. However, Vismodegib is a new upcoming prospect which has shown positive results while undergoing clinical trials. If approved, it may lead to a novel class of anti-cancer therapy for patients seeking treatment for small cell lung cancer.
\end{abstract}

Keywords: Hedgehog, Inhibitors, Lung, Cancer

\section{Letter to the editor}

Lung cancer is an important etiology of malignant mortality worldwide with global statistics indicating over 1 million deaths each year [1]. Despite advances in cytotoxic chemotherapy in addition to traditional treatments, the prognosis still remains poor due to limited efficacy. Remarkably, recent studies on the molecular level have created the possibility to detect, prevent and treat small cell lung cancer in its initial stage by inhibiting a novel pathway involved in embryogenesis known as the Hedgehog $(\mathrm{Hh})$ pathway.

The Hh pathway involves a family of secreted proteins that participate in the regulation of cell growth, differentiation and survival $[2,3]$. Furthermore, these unique proteins have also been implicated in promoting stem cell proliferation in adults. However, if they are abnormally hyperactivated in adult tissues through sporadic mutations or other mechanisms, they may play a crucial role in tumorigenesis of various organs especially the lungs [4-6]. Amongst these, the ones recently discovered to contribute in small cell lung cancer $[7,8]$ development are Smoothened (SMO), Rab23, platelet-derived growth factor alpha (PDGFR $\alpha)$, hedgehog interacting

\footnotetext{
* Correspondence: sh.abbas.naqvi@gmail.com

Dow Medical College, Dow University of Health Sciences, Baba-e-Urdu Road, Karachi, Pakistan
}

protein (HIP) and hepatocyte nuclear factor 3-beta (HNF3 $\beta$ ) [5]. For this reason, the use of Hh pathway inhibitors in lung cancer have strongly been considered.

Hh pathway inhibitors are a novel class of therapeutic agents that specifically target proteins which are involved in the regulation of the Hh pathway. Currently, the inhibitors include IWP-2, cyclopamine and aprotinin; each one altering one of the mutated afore mentioned proteins to prevent malignancy by inhibiting wnt/ $\beta$-catenin pathway [9], blocking hedgehog signaling by binding to heptahelical bundle of smoothened (smo) [10] and as protease inhibitor [11], respectively. In addition, itraconazole (Sporanox) are a different class of drugs which have also shown potential; having the same action as cyclopamine except through a different mechanism [12] while arsenic trioxide antagonizes the Hedgehog pathway by preventing ciliary accumulation thus reducing stability of the Gli2 transcriptional effector [13]. Although these drugs have been successful in treating invasive cancers, their role in lung cancer therapy remains to be determined. Many studies have discussed the potential role of HHIs in small cell lung cancer but a lot of these drugs are still in their trial phase. Various studies discussed new strategies of lung cancer management with a possible role of $\mathrm{HHI}$ in future $[14,15]$. 
Interestingly, Vismodegib (trade name Erivedge) is a new upcoming prospect which has shown positive results for inhibiting the Hh pathway in different cancer while undergoing clinical trials in the United States [16]. It acts to suppress Hh signaling by binding to and interfering with smoothened, a membrane protein that provides positive signals to the $\mathrm{Hh}$ signaling pathway [17]. Moreover, this drug is extensively bound to plasma proteins which accounts for its longer half-life [18]. Its recent approval for the treatment of advanced basal cell carcinoma (BCC) has now made it a viable candidate in lung cancer therapy. However, like other drugs Vismodegib also has side effects including muscle spasms, weight loss, dysguesia, alopecia and constipation [19]. Nevertheless, if Vismodegib is approved by the Food and Drug Administration (FDA) for small cell lung cancer, it may lead to a novel class of anti-cancer therapy for patients seeking treatment for lung cancer. Moreover, these advancements may potentially lead to a cascade of new clinical trials with more Hh inhibiting drugs being tested for their safety and efficacy. Optimistically, these alone, or in combination with traditional therapy, may provide the breakthrough oncologists need in their struggle to find a definite cure. However, for this notion to be successful, collaborative multiinstitutional efforts will be necessary.

\section{Abbreviations}

Hh: Hedgehog; SMO: Smoothened; PDGFRa: Platelet-derived growth factor alpha; HIP: Hedgehog interacting protein; HNF3ß: Hepatocyte nuclear factor 3-beta; BCC: Basal cell carcinoma; FDA: Food and drug administration.

\section{Competing interests}

The authors declare that no conflict of interest exists.

\section{Authors' contributions}

AN was involved in choosing the topic and drafting the original manuscript. $\mathrm{SN}, \mathrm{MB}$ and $\mathrm{MN}$ were involved in critically reviewing the manuscript. All authors have read and approved the manuscript. The authors did not receive any financial support/grants.

Received: 16 January 2013 Accepted: 20 May 2013

Published: 22 May 2013

\section{References}

1. Parkin DM, Bray F, Ferlay J, Pisani P: Global cancer statistics, 2002. CA Cancer J Clin 2005, 55:74-108.

2. Sheikh A, Alvi AA, Aslam HM, et al: Hedgehog pathway inhibitors - current status and future prospects. Infectious Agents and Cancer 2012, 7:29.

3. Varjosalo M, Taipale J: Hedgehog: functions and mechanisms. Genes Dev 2008, 22(18):2454-2472.

4. Thayer SP, Di Magliano MP, Heiser PW, Nielsen CM, Roberts DJ, Lauwers GY, Qi YP, Gysin S, Fernandez-del Castillo C, Yajnik V: Hedgehog is an early and late mediator of pancreatic cancer tumorigenesis. Nature 2003, 425(6960):851-856.

5. Huang S, Yang L, An Y, Ma X, Zhang C, Xie G, Chen ZY, Xie J, Zhang H: Expression of hedgehog signaling molecules in lung cancer. Acta Histochem 2011, 133(5):564-569.

6. Sheng T, Li C, Zhang $X$, Chi S, et al: Activation of the hedgehog pathway in advanced prostate cancer. Mol Cancer 2004, 3(1):29.

7. Watkins DN, Berman DM, Baylin SB: Hedgehog signaling: progenitor phenotype in small-cell lung cancer. Cell Cycle 2003, 2(3):196-8.
8. Watkins DN, Berman DM, Burkholder SG, Wang B, Beachy PA, Baylin SB: Hedgehog signalling within airway epithelial progenitors and in small-cell lung cancer. Nature 2003, 422(6929):313-7.

9. Chen B, Dodge ME, Tang W, et al: Small molecule-mediated disruption of Wnt-dependent signaling in tissue regeneration and cancer. Nat Chem Biol 2009, 5(2):100-107.

10. Chen JK, Taipale J, Cooper MK, Beachy PA: Inhibition of hedgehog signaling by direct binding of cyclopamine to smoothened. Genes Dev 2002, 16(21):2743-8.

11. Latner $A L$, Longstaff $E$, Turner $G A$ : Anti-tumour activity of aprotinin. Br J Cancer 1974, 30(1):60-7.

12. Lin TL, Matsui W: Hedgehog pathway as a drug target: Smoothened inhibitors in development. OncoTargets and Therapy 2012, 5:547-558.

13. Kim J, Lee JJ, Kim J, Gardner D, Beachy PA: Arsenic antagonizes the Hedgehog pathway by preventing ciliary accumulation and reducing stability of the Gli2 transcriptional effector. Proc Natl Acad Sci USA 2010, 107(30):13432-7.

14. Low JA, de Sauvage FJ: Clinical experience with Hedgehog pathway inhibitors. J Clin Oncol 2010, 28(36):5321-6.

15. LoRusso PM, Rudin CM, Reddy JC, et al: Phase I trial of hedgehog pathway inhibitor vismodegib (GDC-0449) in patients with refractory, locally advanced or metastatic solid tumors. Clin Cancer Res 2011, 17(8):2502-11.

16. Dlugosz A, Agrawal S, Kirkpatrick P: Vismodegib. Nat Rev Drug Discov 2012, 11(6):437-438

17. De Smaele E, Ferretti E, Gulino A: Vismodegib, a small-molecule inhibitor of the hedgehog pathway for the treatment of advanced cancers. Curr Opin Investig Drugs 2010, 11(6):707-18.

18. Giannetti AM, Wong H, Dijkgraaf DJP, et al: Identification, Characterization, and Implications of Species-Dependent Plasma Protein Binding for the Oral Hedgehog Pathway Inhibitor Vismodegib (GDC-0449). J Med Chem 2011, 54(8):2592-2601.

19. Genentech: Erivedge [vismodegib; prescribing information]. South San Francisco, CA: Genentech, Inc; 2012

doi:10.1186/1750-9378-8-17

Cite this article as: Naqvi et al:: Present status and upcoming prospects of hedgehog pathway inhibitors in small cell lung cancer therapy. Infectious Agents and Cancer 2013 8:17.

\section{Submit your next manuscript to BioMed Central and take full advantage of:}

- Convenient online submission

- Thorough peer review

- No space constraints or color figure charges

- Immediate publication on acceptance

- Inclusion in PubMed, CAS, Scopus and Google Scholar

- Research which is freely available for redistribution 